\title{
Learning in Adaptive Management: Insights from Published Practice
}

\author{
$\underline{\text { Christo Fabricius }}^{1}$ and Georgina Cundill ${ }^{2}$
}

\begin{abstract}
Adaptive management is often advocated as a solution to understanding and managing complexity in social-ecological systems. Given the centrality of learning in adaptive management, it remains unclear how learning in adaptive management is understood to occur, who learns, what they learn about, and how they learn. We conducted a systematic review using the Thomson Reuters Web of Science, and searched specifically for examples of the practical implementation of adaptive management between 2011 and 2013 , i.e., excluding articles that suggested frameworks, models, or recommendations for future action. This provided a subset of 22 papers that were analyzed using five elements: the aims of adaptive management as stated in each paper; the reported achievements of adaptive management; what was learned; who learned; and how they learned. Our results indicate that, although most published adaptive management initiatives aimed at improvements in biological conservation or ecosystem management, scholars of adaptive management tend to report on learning more about governance and about learning, than about ecosystems or biological conservation. Whereas almost all the papers (91\%) listed improvements in biological conservation and ecosystem management as aims, 59\% reported these as achievements. Whereas only $27 \%$ listed improved governance as an aim, $73 \%$ mentioned this as an achievement. Conservation scientists and academics reporting on adaptive management tend to learn among themselves, and very seldom (18\%) with external stakeholders. Adaptive ecosystem management is dominated by direct assessment and single-loop learning aimed at improving existing practices $(86 \%)$, with about $50 \%$ engaged in double-loop learning and a similar number in deutero-learning (learning about learning). Some adaptive managers $(36 \%)$ combined double-and single-loop learning and the majority of these $(6 / 8)$ reported on conservation achievements. A possible explanation for these findings is that adaptive management is an evolutionary process and in most instances is still in an early pioneering stage, possibly held back by participants' capacity for learning. The constraint of learning capacity may also explain why so few adaptive management initiatives reported on learning with societal stakeholders.
\end{abstract}

Key Words: adaptive management; biological conservation; ecosystem management; governance; social learning

\section{INTRODUCTION}

Adaptive management involves knowledge accumulation through a process aimed at ensuring tight feedbacks between ecosystem change and decision makers (Allen et al. 2011, Westgate et al. 2013) in a structured cycle of conceptualizing, doing, monitoring, reflecting, learning, and adapting. Over time, adaptive management has become a popular response to the challenges of complexity and the demands of a "shifting world" (Hughes et al. 2007:586). Although originally designed to incorporate continuous reflection, adjustment of management actions, and constant experimentation and repetition by managers (Walters and Holling 1990), more recently the approach has been broadened to involve participation by those outside an organization to broaden the knowledge base and reduce conflicts (Stringer et al. 2006, Rist et al. 2013). Adaptive management is widely advocated as a solution to a wide range of issues, including challenges with elusive solutions such as "wicked problems" (Ludwig 2001); complexity and uncertainty in decision making (Holling 1978, Walters 1997); as a remedy for "analysis paralysis" (Snowden and Boone 2007); a solution to communication breakdowns within and between agencies (McCook et al. 2010); a learning tool to increase knowledge (Armitage et al. 2008); a method to tap into traditional and indigenous knowledge (Berkes et al. 2000); a way to link monitoring to decision making (McGeoch et al. 2011); and a method to assess costs, benefits, and risks (Gregory et al. 2006). The goals of adaptive management reflect this wide range of uses (Westgate et al. 2013) and may include improved ecosystem management, better governance, public participation, and responsiveness, a universally accepted goal implicit in the adaptive management concept (Allen et al 2011, Keith et al. 2011, Roux and Foxcroft 2011, Rist et al. 2013). With such wide-ranging possibilities associated with it, many natural resource management agencies, realizing the intricacies of social-ecological systems management, have embraced adaptive management (Runge 2011, Williams 2011).

However, although adaptive management is based on intuitive and practical concepts and should therefore be easy to understand and implement, it has the danger of becoming a catch-all phrase for any type of "trial and error" management (Rist et al. 2013, Westgate et al. 2013). Many scholars (e.g., Walters 1997, Gregory et al. 2006, Stringer et al. 2006, Keith et al. 2011) have critiqued its utility, questioning the over-emphasis on process vs. action and the circularity of learning and reflection. Three issues dominate the numerous critiques of adaptive management: the plurality of interpretation of the concept and its application (Rist et al. 2013); the scarcity of real-life examples (Keith et al. 2011, Rist et al. 2013, Wesgate et al. 2013); and the lack of understanding, clarity, and purpose of the learning component of the process (Allen and Gunderson 2011, Keith et al. 2011).

Given the centrality of learning in adaptive management, it is important to understand how learning is understood to occur. Learning in adaptive management was originally regarded as an iterative process based on the scientific modeling of carefully planned experiments (Walters 1986). It was expected to involve scientists and decision makers setting objectives, planning, taking action, monitoring, and reflecting on outcomes, learning, and taking action again in a cyclical process. Although early work on

${ }^{1}$ Sustainability Research Unit, Nelson Mandela Metropolitan University, South Africa, ${ }^{2}$ Department of Environmental Science, Rhodes University, Grahamstown, South Africa 
adaptive management focused on individual learning, Lee (1993) expanded this by introducing the idea of organized human endeavor as part of adaptive management. For Lee, social learning involved experimentation, conflict, and social change. This insight transformed the mechanistic understanding of learning over short time scales through experiments to a broader view in which learning and change were expected to occur over many decades within both individuals and organizations. Lee expected social learning to take place among resource managers, policy makers, and scientists, who learned how to cope with uncertainty through an iterative process of experimentation that expanded awareness of ecosystem change across scales, and that created opportunities for social change (Lee 1993).

Given the central, and early, focus on learning in adaptive management it is surprising that this component is often taken for granted and seldom critically analyzed. Although several authors (e.g., Allen et al. 2011, Conroy et al. 2011, McCarthy et al. 2011, Rehme et al. 2011, Scholes and Kruger 2011) have conceptually and theoretically discussed learning in the context of adaptive management, few have analyzed learning in a practical context where adaptive management is being implemented (but see Biggs et al. 2011, Clark and Clarke 2011, Marcot et al. 2012). After three decades of experience with adaptive management, researchers and practitioners are no clearer about who learns during the process, what they learn about, and the processes that support the kind of learning outcomes observed or recorded.

The lack of focus on learning in the adaptive management literature is mirrored by the fact that most papers on the topic focus on frameworks and theories, and not on practice. McFadden et al. (2011) found that only $14 \%$ of 96 papers on adaptive management reviewed by them dealt with the practical implementation of adaptive management. Of these, only 5 explicitly focused on learning and reflection. Rist et al. (2013) found that only $8 \%$ of the 187 articles (i.e., 15) on adaptive management published in 2009 reported on real-life experience with the approach, whereas Westgate et al. (2013) found that fewer than $5 \%$ of the 1336 articles they reviewed for the period 1978-2011 explicitly aimed at enacting adaptive management. All these authors called for further discussion and systematic assessment and drew attention to the confusion in terminology and conceptualization.

We systematically assess practical experiences of enacted adaptive management appearing in the Thomson Reuters Web of Knowledge (http://wokinfo.com/citationconnection/) between January 2011 and 20 August 2013. We ask: what are natural resource managers' aims with adaptive management; who learns during adaptive management; what do people learn; and how do they learn? We attempt to explain the reasons for the observed patterns and recommend future arenas for research.

\section{METHODS}

We searched the Thomson Reuters Web of Knowledge literature database for articles published between January 2011 and 20 August 2013 that contained the phrase "adaptive management," and the words "conservation" or "ecosystem" or "ecology" in the title, keywords, or abstract. We deliberately excluded papers with the phrase "adaptive comanagement" in the title because of their explicit emphasis on governance (Olsson et al. 2004, Fabricius et al. 2007, Plummer 2009), arguing that this would skew the sample. Although every effort was made to be unbiased and as thorough as possible, we do not claim this to be a comprehensive collection of adaptive management papers published over that period. Our search yielded a sample of 379 articles. This sample went through a further round of refinement by selecting only those papers that reported on the practical implementation and enactment of adaptive management. We thus excluded papers that presented only frameworks, protocols, or models or merely made recommendations without reflecting on implementation and learning. This left us with a subset of 22 papers, i.e., $6 \%$ of those from the first search. This percentage is in line with the recent experiences of other scholars who found similar percentages of papers referring to the practical implementation of adaptive management (e.g., Rist et al. 2013, Westgate et al. 2013).

Each paper was systematically read and analyzed to extract the following information from it for storage in an annotated database:

- The aims of adaptive management in each case study

- Noted achievements of adaptive management in each case study

- What was learned, including challenges and recommendations

- Who learned during the adaptive management process

- How they learned during the adaptive management process

- Type or category of learning, i.e., single- or double-loop learning, deutero learning, or a combination

The descriptive information was then coded and assigned to subcategories (Table 1) within the six main categories listed above. Most papers were assigned to more than one subcategory within each category.

\section{The main aims of adaptive management}

Five subcategories were identified based on existing literature and after assessing the papers: (i) improved biological conservation and ecosystem management outcomes (Walters 1997, Roux and Foxcroft 2011); (ii) improved governance (Clark and Clarke 2011); (iii) improved public participation (Stringer et al. 2006, Allen and Gunderson 2011, Roux and Foxcroft 2011, Kelly et al. 2012). Two additional subcategories: (iv) learning and understanding (Johnson 2011), and (v) adaptation and responsiveness (PahlWostl 2009), although being inherent traits of adaptive management (Holling 1978), were nevertheless included to verify that papers had been correctly selected.

\section{Achievements of adaptive management}

Papers were assessed for evidence of positive outcomes in the same subcategories as those listed under "aims of adaptive management." Only explicitly stated outcomes were taken into account. 
Table 1. Frequencies of occurrence of various elements of adaptive management appearing in 22 papers published between January 2011 and August 2013. Papers were selected for their focus on the practical implementation of adaptive management, rather than on models and conceptual frameworks.

\begin{tabular}{|c|c|c|c|}
\hline Category & Subcategories & Percentage & Frequency \\
\hline \multirow[t]{5}{*}{ Aims of adaptive management } & Improved adaptation and responsiveness & $100 \%$ & 22 \\
\hline & Learning and understanding & $100 \%$ & 22 \\
\hline & Improved conservation and ecosystem management & $91 \%$ & 20 \\
\hline & Improved governance & $27 \%$ & 6 \\
\hline & Improved public participation & $23 \%$ & 5 \\
\hline \multirow[t]{5}{*}{ Achievements } & Improved adaptation and responsiveness & $100 \%$ & 15 \\
\hline & Improvements in learning and understanding & $91 \%$ & 20 \\
\hline & Improved governance & $73 \%$ & 16 \\
\hline & Improved conservation outcomes & $59 \%$ & 13 \\
\hline & Improved public participation & $36 \%$ & 8 \\
\hline \multirow[t]{8}{*}{ What has been learnt } & Governance & $86 \%$ & 19 \\
\hline & Organizational buy-in & $64 \%$ & 14 \\
\hline & Better aligned systems and processes & $55 \%$ & 12 \\
\hline & Common understanding & $50 \%$ & 11 \\
\hline & & $45 \%$ & 10 \\
\hline & Improved communication & $27 \%$ & 6 \\
\hline & Conservation and ecosystem management & $27 \%$ & 4 \\
\hline & Constituency building and public participation & $20 \%$ & 3 \\
\hline \multirow[t]{3}{*}{ Who has learnt } & Scientists and conservation managers & $64 \%$ & 14 \\
\hline & Scientists and academics only & $50 \%$ & 11 \\
\hline & $\begin{array}{l}\text { Scientists, conservation managers, and societal } \\
\text { stakeholders }\end{array}$ & $18 \%$ & 4 \\
\hline \multirow[t]{3}{*}{ How they have learnt } & Assessment & $64 \%$ & 14 \\
\hline & Experimentation and reflection & $55 \%$ & 12 \\
\hline & Dialogue and oral transfer & $36 \%$ & 8 \\
\hline \multirow[t]{4}{*}{ Modes of learning } & To improve existing practices (single loop) & $86 \%$ & 19 \\
\hline & Reflection and innovation (double loop) & $50 \%$ & 11 \\
\hline & Learning about learning (deutero) & $50 \%$ & 11 \\
\hline & A blend of different types of learning & $36 \%$ & 8 \\
\hline
\end{tabular}

\section{What was learned}

This was assessed by analyzing the learnings explicitly mentioned by the authors as well as implicit learnings such as recommendations stemming from implementation experiences, challenges, and obstacles identified in the papers. Subcategories emerging from our assessment of the papers included: conservation and ecosystem management; constituency building and public participation; and organizational governance. After more detailed assessment we found that "governance," a multifaceted term, could be subdivided into five subareas: strengthened capacity; better aligned systems and processes; common stakeholder understanding; organizational buy-in; and improved communication.

\section{Who learned}

This aspect included three subcategories: scientists only; scientists and conservation managers; and scientists, conservation managers, and societal stakeholders.

How learning took place

This included three preselected subcategories: assessment, i.e., immediate evaluation of performance (Biggs et al. 2011, Williams 2011); dialogue and oral transfer (Berkes et al. 2000, Leys and
Vanclay 2011); and experimentation and reflection (Walters 1986, Lee 1993, Biggs et al. 2011, Moore et al. 2011).

Type or category of learning

This aspect included four subcategories aimed at capturing broader learning processes: learning that leads to improvements in existing practices, i.e., "single-loop learning"( Tosey et al. 2012); learning that leads to reflection, that challenges the status quo, and that explores innovative approaches, also called "double-loop learning" (Tosey et al. 2012); learning about learning or "deuterolearning" (Argyris and Schön 1996, Clark and Clarke 2011, Tosey et al. 2012); and a blend of different learning processes.

\section{RESULTS}

Aims of adaptive management

As can be expected all 22 papers cited adaptation and responsiveness, the central tenet of adaptive management, as an aim. In addition, the vast majority of papers (20) mentioned improved biological conservation and ecosystem management as an aim. Six papers mentioned improved governance as an aim and five aimed for improved participation. 


\section{Achievements of adaptive management}

Twenty of the papers mentioned learning and improved understanding as achievements. After learning, the greatest achievement of adaptive management was reported as improvements in governance, reported in 16 of the papers, compared with only 6 that mentioned it as an aim. Thirteen of the papers listed improved biological conservation outcomes as an achievement, compared with 20 that mentioned it as an aim. The observed and expected frequencies differed significantly ( $\mathrm{P}$ $<0.01$, Chi-square test).

\section{Learning outcomes}

Adaptive managers tend to learn about governance, rather than biological conservation. Nineteen of the 22 papers reported that they learned about governance, compared with eight that reported learning about biological conservation and ecosystem management. Specific governance challenges included a low capacity to implement adaptive management (14); weak organizational understanding of adaptive management (11); lack of buy-in within the organization (10); and poor communication (6). Seven of the papers reported learning about stakeholder participation.

\section{Who learned}

Adaptive ecosystem managers tend to learn among themselves and seldom with external stakeholders. The majority of papers (14) documented learning between professional scientists and managers inside the organization. Eight papers documented learning by conservation scientists and academics without management participation. Only four of the papers provided evidence of learning among professionals and societal stakeholders.

\section{How they learned}

Adaptive ecosystem managers learn mostly through direct assessment and experimentation, but dialogue also plays a role. Fourteen of the papers mentioned learning methods indicative of direct assessment, 12 reported on experimentation, including modeling, and reflection, and 8 mentioned that learning took place through dialogue and oral transfer followed by reflection.

\section{Type or category of learning}

Nineteen of the papers reported learning about improving existing practices, i.e., single-loop learning, while 11 provided evidence of reflective learning that challenged the status quo and explored innovative alternatives, i.e., double-loop learning, and 8 provided evidence of using a blend of both. Eleven of the papers described a process based on learning about learning, i.e., deuterolearning.

\section{DISCUSSION}

Learning to improve current practices, learning to challenge the status quo and innovate, or just learning to learn?

Natural resource management professionals involved in adaptive management learned mostly through assessment, i.e., direct evaluation (e.g., Biggs et al. 2011, Kingsford et al. 2011, Martin and Pope 2011, Bonanno 2013, Giebels et al. 2013), as well as through experimentation and reflection (e.g., Briceño-Linares et al. 2011, Bunnefeld et al. 2011, Johnson 2011, Smith 2011, Van Wilgen et al. 2011, Marcot et al. 2012), and to a lesser extent through dialogue (e.g., Foxcroft and McGeoch 2011, Moore et al. 2011, Pollard et al. 2011, Kelly et al. 2012, Varady et al. 2013).
In the papers we analyzed, the emphasis on assessment is paralleled by the dominance of single-loop learning (e.g., BriceñoLinares et al. 2011, Grant et al. 2011, Holness and Biggs 2011, Kingsford et al. 2011, Martin and Pope 2011, Bonanno 2013), with only a small number of papers (e.g., Biggs 2011, Pollard et al. 2011, Varady et al. 2013) exclusively adopting double-loop learning. However, a significant number of papers showed evidence of the parallel and blended use of single- and doubleloop learning (e.g., Bunnefeld et al. 2011, Johnson 2011, McLoughlin et al. 2011, Moore et al. 2011, Rumpff et al. 2011, Scheepers et al. 2011, Smith 2011, Marcot et al. 2012) by implementing and modifying field experiments or developing, testing, and refining models, consistent with the approach advocated by Walters (1986) and Holling (1978). Ideally, adaptive managers should do both, realizing that a singular focus on double-loop learning will not get the job done and could result in endless cycles of reflection without implementation as suggested by Allen and Gunderson (2011). In ecosystem management single-loop learning is essential to make progress with natural resource management in practice (all 13 papers that provided evidence of conservation achievements also provided evidence of single-loop learning), whereas double-loop learning is essential for innovation and critical appraisal. In fact, in situations in which institutional culture does not permit error, and therefore adaptive management, double-loop learning may be necessary to allow for single-loop learning and the practical adjustment of decision making. However, the challenge in moving beyond "learning for the sake of learning" in adaptive management is to find the appropriate blend or balance between single-loop learning with a focus on doing, and double-loop learning with a focus on reflection and changing practices.

Scholars of organizational learning (Argyris and Schön 1996, Clark and Clarke 2011, Tosey et al. 2012) distinguish between single-loop learning, i.e., learning to improve existing practices, and double-loop learning, i.e., learning that challenges existing practices and explores alternatives. Some organizational theorists have portrayed double-loop learning as more progressive than single-loop learning and have even proposed a third, more advanced type of learning called triple-loop learning (e.g., Flood and Romm 1996, Pahl-Wostl 2009, McCarthy et al. 2011). Contemporary authors such as Tosey et al. (2012), however, believe that double-loop learning is not necessarily more advanced than single-loop learning, and that the two types are complementary rather than one being more advanced than the other. They question the validity of triple-loop learning as a separate category. For that reason triple-loop learning was not included as a category because of its ambiguous definition and challenges to its validity as a stand-alone learning process.

Learning about ecosystems, or about governance and learning? Our data highlight an incongruence between the aims of adaptive management, the achievements reported, and the learning outcomes. Most natural resource management professionals aimed for improved biological conservation and ecosystem management and only a minority explicitly aimed for improved governance. However, a large majority of the achievements centered on learning, understanding, and governance with a smaller than expected proportion focusing on biological conservation. Likewise, the vast majority of learning was about governance-related issues such as better aligned systems and processes, organizational capacity and buy-in, with only a small 
proportion learning about biological conservation. On the whole, most adaptive natural resource managers are learning about learning and governance, not biological conservation. This is also reflected in the substantial proportion of papers that provided evidence of learning about learning, also referred to as deuterolearning, which Tosey et al. (2011:301) views as "reflexivity about processes of learning," i.e., learning how to develop the capacity that improves performance, and learning how to reflect, question, and interrogate norms and values.

\section{Participatory or exclusive learning?}

Given the importance assigned to social change (Lee 1993) and thus more recently participation in adaptive management (Stringer et al. 2006, Allen and Gunderson 2011, Roux and Foxcroft 2011) the low frequency of stakeholder participation reflected in the aims, learning outcomes, and to a lesser extent achievements is remarkable. It seems that, consistent with early conceptualizations of who learns during adaptive management (Walters 1986), most of the learning is occurring between natural resource scientists and managers, with only four of the papers mentioning public participation in learning. It thus appears that despite recent theoretical emphasis on participation in adaptive management, in practice natural resource managers and scientists prefer to learn among themselves. The opposite is probably the case in adaptive comanagement, which we excluded from our analysis, and where the emphasis is placed on participation and governance (Armitage et al. 2008, Plummer et al. 2013). In theory, the advantages of inclusivity include a reduction in conflict and an increase in the pool of knowledge contributing to solutions (Meinke et al. 2009, Rist et al. 2013) but the disadvantage is that, particularly in situations with low capacity or low organizational buy-in, inclusivity can be very costly and time-consuming (Muriti and Murphy Ives 2007). The costs and disadvantages of inclusivity are expected to decrease as organizational buy-in and the capacity for learning gradually increases, however this does not appear to be experienced in practice because all indications are that the costs of inclusivity currently outweigh the advantages for most managers.

\section{Toward a more dynamic conceptualization of learning in adaptive management}

Our analysis raises this question: Why do the majority of adaptive management experiences focus on documenting governancerelated challenges in their learning, rather than learning about ecosystem responses to decision making, and why are external stakeholders not participating in the process? Our data indicates adaptive management is dominated by governance concerns, particularly related to capacity issues, and that this provides a barrier to broadening participation.

\section{CONCLUSIONS}

Although adaptive management is not a catch-all solution to all natural resource management challenges, it is one of the few practical responses to the management challenges posed by complex systems. Situations in which there is high organizational resistance, the system boundaries are unclear, the issues and scales are numerous, and stakeholders are many, are not conducive to adaptive management (Allen and Gunderson 2011) and should best be addressed using more conventional rule-based approaches.
Our findings suggest a number of key foci for future research into adaptive management. First, there is an increasingly obvious paucity of documented empirical examples of adaptive management. Observing the processes and outcomes of adaptive management in practice is therefore a crucial area of future research. Such research must pay attention to the ecological outcomes of the adaptive management process, as well as to the social outcomes as has been the focus to date. A second key area for future research is on the feedbacks between capacity and inclusivity. Our analysis suggests that there may be value in exploring how stakeholders, or shadow networks, interact with adaptive management processes, and in linking this analysis to existing learning theory such as Lave and Wenger's notion of communities of practice (Lave and Wenger 1991). Third, as we realize increasingly that adaptive management is a social process that appears to be more about learning about and managing human relationships than managing ecosystems, we must start to engage seriously with social theory that has a long history of exploring processes of social change. An obvious starting point here would be the work of sociologists such as Archer (2007) who specifically focus on processes of social change.

Responses to this article can be read online at: http://www.ecologyandsociety.org/issues/responses. $\mathrm{php} / 6263$

Acknowledgments:

The National Research Foundation is thanked for their ongoing support of our research.

\section{LITERATURE CITED}

Allen, C. R., J. J. Fontaine, K. L. Pope, and A. S. Garmestani. 2011. Adaptive management for a turbulent future. Journal of Environmental Management 92:1339-1345.

Allen, C. R., and L. H. Gunderson. 2011. Pathology and failure in the design and implementation of adaptive management. Journal of Environmental Management 92:1379-1384. http://dx. doi.org/10.1016/j.jenvman.2010.10.063

Archer, M. S. 2007. Making our way through the world: human reflexivity and social mobility. Cambridge University Press, New York, New York, USA. http://dx.doi.org/10.1017/CBO9780511618932

Argyris, C., and D. A. Schön. 1996. Organizational learning II: theory, method and practice. Addison-Westley, Reading, Massachusetts, USA.

Armitage, D., M. Marschke, and R. Plummer. 2008. Adaptive comanagement and the paradox of learning. Global Environmental Change 18:86-98. http://dx.doi.org/10.1016/j.gloenvcha.2007.07.002

Berkes, F., J. Colding, and C. Folke. 2000. Rediscovery of traditional ecological knowledge as adaptive management. Traditional Ecological Knowledge 10:1251-1262.

Biggs, H., S. Ferreira, S. Freitag-Ronaldson, and R. Grant-Biggs. 2011. Taking stock after a decade: does the 'thresholds of potential concern' concept need a socio-ecological revamp? 
Koedoe 53(2) Art. \#1002. http://dx.doi.org/10.4102/koedoe. v54i1.1002

Bonanno, G. 2013. Adaptive management as a tool to improve the conservation of endemic floras: the case of Sicily, Malta and their satellite islands. Biodiversity and Conservation 22:1317-1354. http://dx.doi.org/10.1007/s10531-013-0473-9

Briceño-Linares, J. M., J. P. Rodríguez, K. M. Rodríguez-Clark, F. Rojas-Suárez, P. A. Millán, E. G. Vittori, and M. CarrascoMuñoz. 2011. Adapting to changing poaching intensity of Yellow-shouldered Parrot (Amazona barbadensis) nestlings in Margarita Island, Venezuela. Biological Conservation 144:1188-1193. http://dx.doi.org/10.1016/j.biocon.2010.12.010

Bunnefeld, N., E. Hoshino, and E. J. Milner-Gulland. 2011. Management strategy evaluation: a powerful tool for conservation? Trends in Ecology \& Evolution 26:441-447. http:// dx.doi.org/10.1016/j.tree.2011.05.003

Clark, J. R. A., and R. Clarke. 2011. Local sustainability initiatives in English National Parks: what role for adaptive governance? Land Use Policy 28:314-324. http://dx.doi.org/10.1016/j. landusepo1.2010.06.012

Conroy, M. J., M. C. Runge, J. D. Nichols, K. W. Stodola, and R. J. Cooper. 2011. Conservation in the face of climate change: the roles of alternative models, monitoring, and adaptation in confronting and reducing uncertainty. Biological Conservation 144:1204-1213. http://dx.doi.org/10.1016/j.biocon.2010.10.019

Fabricius, C., C. Folke, G. Cundill, and L. Schultz. 2007. Powerless spectators, coping actors, and adaptive co-managers: a synthesis of the role of communities in ecosystem management. Ecology and Society 12(1): 29. [online] URL: http://www.ecologyandsociety. org/vol12/iss1/art29/

Flood, R. L., and N. R. A. Romm. 1996. Plurality revisited: diversity management and triple loop learning. Systems Practice 9:587-603. http://dx.doi.org/10.1007/BF02169215

Foxcroft, L. C., and M. McGeoch. 2011. Implementing invasive species management in an adaptive management framework. Koedoe 53(2) Art. \#1006. http://dx.doi.org/10.4102/koedoe. $\underline{\mathrm{v} 53 \mathrm{i} 2.1006}$

Giebels, D., A. van Buuren, and J. Edelenbos. 2013. Ecosystembased management in the Wadden Sea: principles for the governance of knowledge. Journal of Sea Research 82:176-187. http://dx.doi.org/10.1016/j.seares.2012.11.002

Grant, R. C. C., M. J. S. Peel, and H. Bezuidenhout. 2011. Evaluating herbivore management outcomes and associated vegetation impacts. Koedoe 53(2) Art. \#1008. http://dx.doi. org/10.4102/koedoe.v54i1.1008

Gregory, R., D. Ohlson, and J. Arvai. 2006. Deconstructing adaptive management: criteria for applications to environmental management. Ecological applications 16:2411-2425. http://dx.doi. org/10.1890/1051-0761(2006)016[2411:DAMCFA]2.0.CO;2

Holling, C. S. 1978. Adaptive environmental assessment and management. John Wiley, London, UK.

Holness, S. D., and H. C. Biggs. 2011. Systematic conservation planning and adaptive management. Koedoe 53(2) Art. \#1029. http://dx.doi.org/10.4102/koedoe.v54i1.1029
Hughes, T. P., L. H. Gunderson, C. Folke, A. H. Baird, D. Bellwood, F. Berkes, B. Crona, A. Helfgott, H. Leslie, J. Norberg, M. Nyström, P. Olsson, H. Österblom, M. Scheffer, H. Schuttenberg, R. S. Steneck, M. Tengö, M. Troell, B. Walker, J. Wilson, and B. Worm. 2007. Adaptive management of the Great Barrier Reef and the Grand Canyon World Heritage Areas. Ambio 36:586-592. http://dx.doi.org/10.1579/0044-7447(2007)36[586: AMOTGB]2.0.CO;2

Johnson, F. A. 2011. Learning and adaptation in the management of waterfowl harvests. Journal of Environmental Management 92:1385-1394. http://dx.doi.org/10.1016/j.jenvman.2010.10.064

Keith, D. A., T. G. Martin, E. McDonald-Madden, and C. Walters. 2011. Uncertainty and adaptive management for biodiversity conservation. Biological Conservation 144:1175-1178. http://dx.doi.org/10.1016/j.biocon.2010.11.022

Kelly, M., S. Ferranto, S. Lei, K.-i. Ueda, and L. Huntsinger. 2012. Expanding the table: the web as a tool for participatory adaptive management in California forests. Journal of Environmental Management 109:1-11. http://dx.doi.org/10.1016/ j.jenvman.2012.04.035

Kingsford, R. T., H. C. Biggs, and S. R. Pollard. 2011. Strategic adaptive management in freshwater protected areas and their rivers. Biological Conservation 144:1194-1203. http://dx.doi. org/10.1016/j.biocon.2010.09.022

Lave, J., and E. C. Wenger. 1991. Situated learning: legitimate peripheral participation. Cambridge University Press, Cambridge, UK. http://dx.doi.org/10.1017/CBO9780511815355

Lee, A.-R. 1993. Culture shift and popular protest in South Korea. Comparative Political Studies 26:63-80. http://dx.doi. org/10.1177/0010414093026001003

Leys, A. J., and J. K. Vanclay. 2011. Social learning: a knowledge and capacity building approach for adaptive co-management of contested landscapes. Land Use Policy 28:574-584. http://dx.doi. org/10.1016/j.landusepol.2010.11.006

Ludwig, D. 2001. The era of management is over. Ecosystems 4:758-764. http://dx.doi.org/10.1007/s10021-001-0044-x

Marcot, B. G., M. P. Thompson, M. C. Runge, F. R. Thompson, S. McNulty, D. Cleaves, M. Tomosy, L. A. Fisher, and A. Bliss. 2012. Recent advances in applying decision science to managing national forests. Forest Ecology and Management 285:123-132. http://dx.doi.org/10.1016/j.foreco.2012.08.024

Martin, D. R., and K. L. Pope. 2011. Luring anglers to enhance fisheries. Journal of Environmental Management 92:1409-1413. http://dx.doi.org/10.1016/j.jenvman.2010.10.002

McCarthy, D. D. P., D. D. Crandall, G. S. Whitelaw, Z. General, and L. J. S. Tsuji. 2011. A critical systems approach to social learning: building adaptive capacity in social, ecological, epistemological (SEE) systems. Ecology and Society 16(3): 18. http://dx.doi.org/10.5751/ES-04255-160318

McCook, L. J., T. Ayling, M. Cappo, J. H. Choat, R. D. Evans, D. M. De Freitas, M. Heupel, T. P. Hughes, G. P. Jones, B. Mapstone, H. Marsh, M. Mills, F. J. Molloy, C. R. Pitcher, R. L. Pressey, G. R. Russ, S. Sutton, H. Sweatman, R. Tobin, D. R. Wachenfeld, and D. H. Williamson. 2010. Adaptive management of the Great Barrier Reef: a globally significant demonstration 
of the benefits of networks of marine reserves. Proceedings of the National Academy of Sciences 107:18278-18285. http://dx.doi. org/10.1073/pnas.0909335107

McFadden, J. E., T. L. Hiller, and A. J. Tyre. 2011. Evaluating the efficacy of adaptive management approaches: is there a formula for success? Journal of Environmental Management 92:1354-1359. http://dx.doi.org/10.1016/j.jenvman.2010.10.038

McGeoch, M. A., H. Sithole, M. J. Samways, J. P. Simaika, J. S. Pryke, M. Picker, C. Uys, A. J. Armstrong, A. S. DippenaarSchoeman, I. A. Engelbrecht, B. Braschler, and M. Hamer. 2011. Conservation and monitoring of invertebrates in terrestrial protected areas. Koedoe 53(2) Art. \#1000. http://dx.doi. org/10.4102/koedoe.v54i1.1000

McLoughlin, C. A., A. Deacon, H. Sithole, and T. Gyedu-Ababio. 2011. History, rationale, and lessons learned: thresholds of potential concern in Kruger National Park river adaptive management. Koedoe 53(2) Art. \#996. http://dx.doi.org/10.4102/ koedoe.v54i1.996

Meinke, H., S. M. Howden, P. C. Struik, R. Nelson, D. Rodriguez, and S. C. Chapman. 2009. Adaptation science for agriculture and natural resource management - urgency and theoretical basis. Current Opinion in Environmental Sustainability 1:69-76. http:// dx.doi.org/10.1016/j.cosust.2009.07.007

Moore, C. T., E. V. Lonsdorf, M. G. Knutson, H. P. Laskowski, and S. K. Lor. 2011. Adaptive management in the U.S. National Wildlife Refuge system: science-management partnerships for conservation delivery. Journal of Environmental Management 92:1395-1402. http://dx.doi.org/10.1016/j.jenvman.2010.10.065

Muriti, T., and P. Murphy Ives. 2007. Under the acacia: mediation and the dilemma of inclusion. Africa Mediators Retreat 7:77-86.

Olsson, P., C. Folke, and F. Berkes. 2004. Adaptive comanagement for building resilience in social-ecological systems. Environmental Management 34:75-90. http://dx.doi.org/10.1007/s00267-003-0101-7

Pahl-Wostl, C. 2009. A conceptual framework for analysing adaptive capacity and multi-level learning processes in resource governance regimes. Global Environmental Change 19:354-365. http://dx.doi.org/10.1016/j.gloenvcha.2009.06.001

Plummer, R. 2009. The adaptive co-management process: an initial synthesis of representative models and influential variables. Ecology and Society 14(2): 24. [online] URL: http://www. ecologyandsociety.org/vol14/iss2/art24/

Plummer, R., D. R. Armitage, and R. C. de Löe. 2013. Adaptive comanagement and its relationship to environmental governance. Ecology and Society 18(1): 21. http://dx.doi.org/10.5751/ ES-05383-180121

Pollard, S., D. Du Toit, and H. Biggs. 2011. River management under transformation: the emergence of strategic adaptive management of river systems in the Kruger National Park. Koedoe 53(2) Art. \#1011. http://dx.doi.org/10.4102/koedoe. $\underline{\mathrm{v} 54 \mathrm{i} 1.1011}$

Rehme, S. E., L. A. Powell, and C. R. Allen. 2011. Multimodel inference and adaptive management. Journal of Environmental Management 92:1360-1364. http://dx.doi.org/10.1016/j.

jenvman.2010.10.012
Rist, L., B. Campbell, and P. Frost. 2013. Adaptive management: where are we now? Environmental Conservation 40:5-18. http://dx. doi.org/10.1017/S0376892912000240

Roux, D. J., and L. C. Foxcroft. 2011. The development and application of strategic adaptive management within South African National Parks. Koedoe 53(2) Art. \#1049. http://dx.doi. org/10.4102/koedoe.v54i1.1049

Rumpff, L., D. H. Duncan, P. A. Vesk, D. A. Keith, and B. A. Wintle. 2011. State-and-transition modelling for adaptive management of native woodlands. Biological Conservation 144:1224-1236. http://dx.doi.org/10.1016/j.biocon.2010.10.026

Runge, M. C. 2011. An introduction to adaptive management for threatened and endangered species. Journal of Fish and Wildlife Management 2:220-233. http://dx.doi.org/10.3996/082011-JFWM-045

Scheepers, K., L. Swemmer, and W. J. Vermeulen. 2011. Applying adaptive management in resource use in South African National Parks: a case study approach. Koedoe 53(2) Art. \#999. http://dx. doi.org/10.4102/koedoe.v54i1.999

Scholes, R. J., and J. M. Kruger. 2011. A framework for deriving and triggering thresholds for management intervention in uncertain, varying and time-lagged systems. Koedoe 53(2) Art. \#987. http://dx.doi.org/10.4102/koedoe.v54i1.987

Smith, C. B. 2011. Adaptive management on the central Platte River - science, engineering, and decision analysis to assist in the recovery of four species. Journal of Environmental Management 92:1414-1419. http://dx.doi.org/10.1016/j.jenvman.2010.10.013

Snowden, D. J., and M. Boone. 2007. A leader's framework for decision making. Harvard Business Review 85:69-76. http://dx. doi.org/10.1037/e706682007-002

Stringer, L. C., A. J. Dougill, E. Fraser, K. Hubacek, C. Prell, and M. S. Reed. 2006. Unpacking "participation" in the adaptive management of social-ecological systems: a critical review. Ecology and Society 11(2): 39. [online] URL: http://www. ecologyandsociety.org/vol11/iss2/art39/

Tosey, P., M. Visser, and M. N. K. Saunders. 2012. The origins and conceptualizations of 'triple-loop' learning: a critical review. Management Learning 43:291-307. http://dx.doi. org/10.1177/1350507611426239

Van Wilgen, B. W., N. Govender, G. G. Forsyth, and T. Kraaij. 2011. Towards adaptive fire management for biodiversity conservation: experience in South African National Parks. Koedoe 53(2) Art. \#982. http://dx.doi.org/10.4102/koedoe. v54i1.982

Varady, R. G., C. A. Scott, M. Wilder, B. Morehouse, N. P. Pablos, and G. M. Garfin. 2013. Transboundary adaptive management to reduce climate-change vulnerability in the western U.S.Mexico border region. Environmental Science \& Policy 26:102-112. http://dx.doi.org/10.1016/j.envsci.2012.07.006

Walters, C. 1986. Adaptive management of renewable resources. MacMillan, New York, New York, USA.

Walters, C. J. 1997. Challenges in adaptive management of riparian and coastal ecosystems. Conservation Ecology 1(2): 1. [online] URL: http://www.ecologyandsociety.org/vol1/iss2/art1/ 
Walters, C. J., and C. S. Holling. 1990. Large-scale management experiments and learning by doing. Ecology 71:2060-2068. http:// dx.doi.org/10.2307/1938620

Westgate, M. J., G. E. Likens, and D. B. Lindenmayer. 2013. Adaptive management of biological systems: a review. Biological Conservation 158:128-139. http://dx.doi.org/10.1016/j.biocon.2012.08.016

Williams, B. K. 2011. Adaptive management of natural resourcesframework and issues. Journal of Environmental Management 92:1346-1353. http://dx.doi.org/10.1016/j.jenvman.2010.10.041 